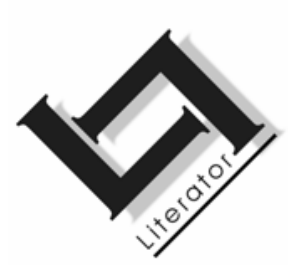

\title{
The crucial role of literature in the generation of knowledge and critical thinking
}

Marita Wenzel

School of Languages: English

Potchefstroom Campus

North-West University

POTCHEFSTROOM

E-mail: engmjw@puk.ac.za

\section{Abstract}

The crucial role of literature in the generation of knowledge and critical thinking

This article addresses two major issues in education today: the generation and processing of knowledge and the crucial role of the humanities, literature in particular, in the development of students with individual world views and unique senses of identity. The article presents an argument for a holistic and open-ended (as opposed to prescriptive) approach to knowledge generation and proposes the acknowledgement of differences and choices that should be considered in the construction of future scenarios for educational practices. The argument is less concerned with content (that is, the syllabus as such) or the practicalities of education, than with the basic approach to and facilitation of the process of education and knowledge acquisition within specific cultural and social contexts and the role of literature in that process.

\section{Opsomming}

Die kardinale rol van letterkunde in die verwerwing van kennis en kritiese denke

Hierdie artikel bespreek twee belangrike aspekte van die huidige onderrigsituasie: die verwerwing en prosessering van kennis en die kardinale rol van die humaniora, en veral die letterkunde, in die ontwikkeling van studente met individuele lewensbeskouings en unieke persepsies van identiteit. Die artikel bepleit 'n holistiese en oop (in teenstelling met 'n voorskrywende) benadering tot kennis- 
verwerwing en stel voor dat verskille en keuses erken en oorweeg moet word in toekomstige beplanning vir onderrig in die praktyk. Die argument handel minder oor inhoud (die kurrikulum) of die praktiese implementering van onderrig, as oor die basiese benadering tot en die fasilitering van die onderrigproses en kennisverwerwing binne spesifieke en sosiale kontekste, asook die rol van letterkunde in daardie proses.

\section{Introduction: Skills versus knowledge}

This article addresses two major issues in education today: the generation and processing of knowledge and the crucial role of the humanities, literature in particular, in the development of students with individual world views and unique senses of identity. The discussion proposes an open ended approach to knowledge generation and suggests that differences and choices should be acknowledged and considered in the construction of future scenarios for educational practices. The argument is less concerned with content (that is, the syllabus as such) or the practicalities of education, than with the basic approach to and facilitation of the process of knowledge acquisition within specific cultural and social contexts and the role of literature in that process.

At present, our universities (and high schools) are challenged by "a global emphasis on educational massification, skills, and outcomes, and the demand for vocational relevance by students who, according to university managerialism, are customers" (Chapman, 2000:44). To accommodate the growing number of students, and to address imbalances in their educational background, the emphasis has increasingly been placed on the development of skills acquired through computer programmes. But, the question remains whether skills as such have much value if they are not applied correctly? In this respect I would like to refer to Nelson's (2002:6) definition of education as distinctive from training (or skills acquisition):

Education in its broadest sense is something that gives meaning to our society. It leads to the deeper development of the person, and creates a broader understanding and perspective of the society in which we each live. A broad education gives strength and texture to our society.

However, Nelson does not deny the value of training which, in contrast to education, "leads to the acquisition of skills for which there are quite clear applications" (Nelson, 2002:6). Student education should therefore include both these competencies that Nelson (2002:10) refers to as "graduate attributes": 
The graduate attribute concept recognises that university education is about more than specific skills-based competencies. It also tries to take into account the desire of the general community, and employers in particular, to prove through definition and measurement that students are developing generic skills as a result of their deeper educative process.

Computer programmes do not equip learners with the essential context and the ability to piece together the "whole picture". Apart from the limited capabilities of computer programmes with reference to knowledge processing, Hassan (2002:47) also points out that technological learning requires constant upgrading and replacement of obsolete systems and cautions that "there is no definitive, demonstrable and empirical research that show the benefits in improved educational outcomes" as a result of technological learning.

My argument posits that skills should not be regarded as the most important component in education, but that they should form part of a more comprehensive focus on lasting values and forms of knowledge. Although computers and other technological aids facilitate the acquisition of certain skills and enable ready access to information, they are only intermediaries in the education process. The learner must, in the final instance, digest this information and be able to apply it meaningfully in different situations. ${ }^{1}$ Hassan (2002:37) explains that his opposition to globalisation and information technology resides mainly in the fact that it

valorises, more than ever before, instrumentalised knowledge over critical forms, and is producing a society that is increasingly unable to think reflexively about the issues and challenges that confront an increasingly complex world.

Haahr (2002:78) cautions that the development of leaders with longterm goals who are "skilled" in planning needs both the acquisition of skills and subsequent generation of knowledge. He visualises this process in terms of a "feedback loop" described as follows: "Learning a vocational skill can be seen as the input portion of the loop and achieving the general understanding as the reflection/

1 Hassan (2002:42) gives the following interpretation of critical thinking: "Critical thinking utilises our capacities for reflecting on ourselves and the systems in which we live. Through this lens of criticality we are able to appreciate that the world is not simply self-evident and given." 
processing part." His contention, that more emphasis and energy is placed on the input portion than on the processing portion, serves to support my argument for the application of skills and their development into knowledge. As Klopper (2000:1) remarks, students are becoming more market related and skills oriented but they lack application. I perceive this to be like learning vocabulary, but never learning to recognise how it is used within the patterns of language.

\section{The generation of knowledge}

A clear distinction should therefore be made between skills, information and knowledge. In fact, this process or chain of development should be extended to include "wisdom" in the sense that Fleming (2000) uses it to indicate processed thinking. Fleming (2000:460) claims that the "wisdom paradigm" originating in the 19th century was based on abstract thinking. Subsequently, this concept was replaced in the 20th century by the "knowledge paradigm" which does not quite serve its purpose anymore. ${ }^{2}$ Fleming (2000:470) proposes that the "knowledge paradigm" should be replaced by a "new" more flexible "wisdom paradigm" that might extend the possibilities of the former and obviate the limitations of the 20th century "knowledge paradigm". Peters (2002:27) in turn, points out that the terms knowledge and information are often used interchangeably and he refers to the definition of knowledge taken from analytic philosophy as a concept based on three conditions: "a belief condition, a truth condition and a justification condition". In consideration of these views, I shall use the word knowledge to indicate the final stage in thought processing and insight.

How do we bridge the gaps between skills and knowledge pointed out above? I would like to suggest that it is not so much the volume (or composition) of the subjects we teach that needs to be revised, as the means by which we facilitate those skills and data or information to enable the generation of knowledge. The Department of Education has attempted to address and re-dress the problem of multicultural classrooms, educational inequality and traditional teaching methods by instituting the concept of Outcomes Based Education. In my opinion, this type of education, focusing on learnercentred instead of traditional teacher-oriented education, could successfully promote the development of independent and

2 Obviously, my use of the term knowledge differs in degree and intensity from his. My term would rather correlate with his idea of "wisdom". 
responsible learners, with the proviso that they are guided by wellequipped and knowledgeable facilitators. As Felicity Rosslyn $(1999: 22)$ unequivocally points out, the changes in information retrieval, student demographics and modularisation alter what we teach and the way we teach it.

Students must learn to ask questions and participate in the experience of reading and interpretation. Yet, the teacher/facilitator also has a responsibility to remain as accessible and flexible as possible. Such an attitude implies interaction with the class. Muldoon (1990:37) provides an example of such flexibility when she describes the classroom as a "community of learners" together with the facilitator, "who, as a fellow prober, is also engaged in meaningful interpretive and composing problems but who also relies on the community to expand the quality and range of that thought".

Learner-centred education, skills acquisition and information collection should not be the sole purpose and goal of reformation in the educational network or system. Facilitators or teachers should play important roles in the eventual processing of knowledge and in the cultivation or generation of cultural awareness. Commenting on an opinion poll on education conducted in 2001 in the USA, MaryEllen Phelps Deily (2002:5) reports that one of the Americans' top priorities for improving education in 2002 was to raise teaching quality (it attained $30 \%$ as opposed to the next issue, which drew $16 \%$ of the votes).

In a comprehensive analysis of subject formation in the humanities, and literature in particular, Gerda Dullaart (2002) raises an important educational issue in literature teaching and its role in the formation of responsible citizens. It concerns the plight of students who, schooled in literary thinking, are nevertheless ignorant of how to implement or interpret the practical benefits of such an education. In an interesting perspective on the question of skills and their application, Gerda Dullaart's Ph.D. thesis (2002:181-182) addresses the situation of literature graduates and the difficulties they experience in finding suitable positions on the job market. She attributes this dilemma mostly to their inability to recognise and interpret their implicit skills (such as communication, adaptability, critical thinking and argumentation skills) attained through the study of literature, as well as an inability to correlate and apply them to various fields of communicative skills in the job market (Dullaart, 2002:190). 


\section{The role of literature in the formation of a social/ personal identity and world view}

\subsection{Literature and culture}

Where does literature then feature in this scenario? I would like to suggest that literature acts as a facilitator for culture, language and critical thinking. To put it succinctly: students who are proficient in language and writing skills can express themselves better and with more conviction. However, language is acquired through literature (factual and fictional) which, apart from cultural and social information, also facilitates personal experience and caters for mental and spiritual needs. Perhaps I should emphasise that I am speaking from an English lecturer's point of view, but I acknowledge that the other languages and disciplines in the humanities fulfil a similar role in the shaping of mentalities and lives.

Cultural perceptions appear to be a key issue in personal and social relations. One-sided or biased cultural impressions play an important role in the reality of unmotivated, under-performing and badly equipped students in a multicultural student body. Bridging the gap in educational background with the focus on skills, is therefore not sufficient to ensure good results. The problem reaches further back and is more complex than that. Literature could successfully be introduced to resolve this gap: it not only improves language proficiency, but hones the intellect, creates room for self-reflection and cultural comparison.

However, we have to acknowledge that culture and civilisation are loaded words in our postcolonial context, as Laurence Wright (1999) very diplomatically points out in his attempt to distinguish between the connotations and implications that these concepts have acquired. Wright $(1999: 61)$ points out that in the European interpretation of these concepts at the beginning of the 20th century, the word culture retained an individual character, while civilisation was seen as "inherently transcultural, to some extent metacultural". Although his argument is much more complex and focuses on the concept of an African renaissance, he voices a word of caution about the tendency to confuse culture and civilisation and subsequently, subsuming them under globalisation. In fact, he predicts that lack of attention to culture could result in "a vague cosmopolitan syncretism, rootless consumerism and unattached fantasy" (Wright 1999:72). 
Although Michael Chapman (2000:53) acknowledges that literature might not be regarded as essential when the exigencies of daily living in South Africa are considered, he cautions that the value of literature and as repositories of culture, should not be ignored:

The challenge is how to convince a society in dire need of job creation healthcare, literacy and learning that another form of impoverishment is a diminishing of the moral and imaginative intelligence. How to retain an ethical dimension at a time when consumerism celebrates buying and spending without obligation to critical reflection? How to retain the news of the world in the formality of the arts?

Literature provides a means for comparison, for the appreciation of difference, as well as the affirmation of the self (one's own culture and traditions). Reading about other cultures does not mean one has to endorse their traditions, but acknowledge them, attempt to accommodate them and adjust one's perceptions. If we wish to educate versatile thinkers and innovators, we do not want to strive for uniformity that would incur mediocrity, but to celebrate difference and individuality, that would stimulate social and intellectual development. In an article on the concepts of negative and positive freedom, Hans Blokland (1998:63-64) addresses the question of individuality and identity and spells out the advantages for a person equipped with knowledge of more than one culture, when he suggests the following:

Individuen die in het bezit zijn van meer 'cultuur' hebben derhalve doorgaans ook een grotere kans op een autonoom bestaan. Omdat zij op de hoogte zijn met alternatieve ideeën, waarden, opvattingen, smaken, stijlen, enzovoorts, zijn zij immers eerder in staat reële keuzen in hun leven te maken, keuzen die dus niet worden bepaald door onwetendheid, vooroordeel of gewoonte.

[Individuals who possess more 'culture' therefore generally have a better chance for an autonomous existence. Because they are well-informed about alternative ideas, values, perceptions, tastes, styles, etcetera, they are always more capable of making relevant choices in their lives, choices which are not determined by ignorance, prejudice or habit.]

Society also implies a value system. In a fascinating article about values, Satya Mohanty (2001) explores the relation between ethics and aesthetics. Mohanty (2001:815) claims that values are "social, even when they are refracted though an individual's beliefs and personal needs. But they should not be seen as purely internal to a 
given society, culture, or civilization either." As he (Mohanty, 2001:805) explains: "values often refer to facts and properties that exist independently of our beliefs", which makes it possible to appreciate cultural and social diversity (Mohanty, 2001:828) from a realist perspective. He also maintains that "the best form of inquiry into the nature of value, aesthetic or ethical, will need to be comparative and cross-cultural because we wish to avoid cultural parochialism and provincialism" (Mohanty, 2001:829).

If we were to adhere to Blokland's (1998:62) contention that freedom should not be associated with non-intervention, but with individual autonomy, a variety of cultures and different perspectives would have to be studied in the literary syllabus in order to educate and cultivate informed and well-balanced citizens. This sentiment is also voiced by Mike Kissack (2001) in his article on literature education in South Africa. Kissack (2001:87) argues that

[p]roposals for the future of literary education in South Africa can only be consistent with multicultural tenets if it incorporates the kinds of texts and perspectives that are at variance with our common understanding of the constitutive values of contemporary liberal and progressive society.

\subsection{Multicultural texts}

The reading of texts should focus on individual interpretation of literary works rather than on the content or composition of the prescribed texts. In such an approach, students would be able to recognise political priorities and ideological prejudice and learn to accommodate them more readily. In fact, as Palazzo (1990:145) maintains, students should "feel that their particular cultural or ideological heritage is acceptable and that they are equipped with enough background knowledge to make sense of the material they are given". The reader's construction of meaning would then become the important point of orientation.

Learners should be able to relate to their immediate context, but they should not be fed on a uniform diet of only one kind of literature such as, for instance, African or Western literature. Students only learn about themselves when they are able to compare themselves and their conditions with others (as Blokland so convincingly argues above about the value of choice). Chetty (2000:14) points out that it is important to understand how the texts affect the reader and how his perceptions of the self and society are shaped by his expanded knowledge and resultant constructions of meaning. The focus is 
then squarely placed on the individual's awareness. For instance, Swart (2000:72) maintains: 'In a postmodern world where 'truth' is even more elusive than before, students need to explore the ways in which what counts for truth is determined by the discursive and rhetorical practices of a culture or a community." Students must realise that there are no correct answers in literature (Rosslyn, 1999:23), but rather "multiple solutions" as Muldoon (1990:34) suggests. In recognition of the multicultural composition of the student body in South Africa, and the crucial importance of critical thinking, the facilitator should strive to accommodate difference and create a broader horizon for the promotion of individual perspective.

The importance of different perspectives determines the interpretation of a specific text: each reader will gain a different set of perceptions with regard to language patterns, the interpretation of literary conventions, the recognition of themes, identification of images and the attainment of perspective with regard to personal and universal applications. This fact is in line with the individual student's progress and learning curve. Learners should be encouraged to guess, to construct and trust their own frames of reference. On the whole, students seem unwilling to take such a responsibility. For instance, in some of the novels by Maori authors like Witi Ihimaera, Patricia Grace and Kerry Hulme, the students seem disconcerted when they are confronted with Maori words that are not necessarily explained in glossaries and hesitant to guess the meanings or to construct their own interpretations from the relevant contexts.

Dasenbrock (1987) discusses the criteria of "intelligibility and meaningfulness" in an article on multicultural literature in which he identifies and criticises two stances evinced by critics: the universalist as opposed to the local and particular. He regards both factions as prescriptive and judges their perceptions of intelligibility to be absolutist (1987:12). In reaction to such interpretations, he posits:

Multicultural literature offers us above all an experience of multiculturalism, in which not everything is likely to be wholly understood by every reader. The texts often only mirror the misunderstandings and failures of intelligibility in the multicultural situations they depict...

What Dasenbrock (1987:14) implies is that the reader should work to make a text intelligible. He (Dasenbrock, 1987:16) points out that Ihimaera actually uses Maori words to emphasise the different 
cultural assumptions that separate the pakeha (Europeans) and Maori cultures. The main point that Dasenbrock (1987:18) wishes to emphasise, is that the multicultural quality of texts also finds resonance in a multicultural readership. His argument for allowing scope in interpretation (intelligibility and meaningfulness), precludes both the universalist and local or particular readership (in this case the students mentioned above), because they deny themselves access to multicultural experience. The students' reactions provide a typical example of Hassan's (2002:50) claim that the "domination of instrumental forms of knowledge" has marginalised critical thinking. In turn, "a lack of a capacity for critical thinking leads inexorably to a lack of imagination" that would prevent us from formulating acceptable alternatives in order to "provide us with other possibilities, other ways of being and seeing." 3 Hassan (2002:50) also relates this lack of an adventurous spirit to a loss of a sense of history and the ability "to situate ourselves historically and to think critically about contemporary issues."

\subsection{Telling stories}

I would like to suggest that literature provides a perfectly simple and effective tool for upgrading skills and acquiring information and should therefore form a crucial part of any educational syllabus. I was told that all students at universities in Russia are compelled to take a course of Russian literature. In my opinion they are thus made aware of their culture and their unique context. To study literature means to study human communication and culture. In fact, all of us communicate every day of our lives and, whether we admit it or not, we also tell stories, because to communicate means to formulate a message. Literature fulfils this role. By telling "stories" about ourselves (especially to come to terms with personal grief or political injustice) or about other people or events that the media report on every day, is the way we try to make sense of our world.

In a fascinating Ph.D. thesis on the origins of myths and their influence on social adaptation, Van Schalkwyk (2003:25) refers to the human's inclination to mythologise his/her experience in reaction to historical contexts. He perceives the presence of myths in life stories and histories as crucial for the individual's understanding of his/her world (Van Schalkwyk, 2003:8). He argues that people tend

3 Radovan (2002:56) echoes this sentiment by referring to the limitation of "the horizon of what may constitute reality" and the capacity for "imaginative and creative thinking". 
to approach reality from a narrative stance for the sake of coherence. In other words, stories or narratives constitute a means of identity formation. Schick (1999:21) also acknowledges the crucial role of narrative in the determination of identity, when he claims that "narrative plays a central role in the constitution and preservation of identity. Narrative is a carrier of meaning, the channel through which an individual tells him/herself and others the tale of his/her place in the world". Schick (1999:21) also stresses the social character of fiction when he says that an

informal body of knowledge that determines the limits of the possible and provides individuals with roadmaps to the societal landscape, is acquired, reproduced, and transmitted through narrative. Indeed, not only do such patterns or structures determine individuals' behavior in the world, they also define their identities.

Stories form an important part of our daily repertoire: they act as forms of self-discovery, therapy and models of behaviour. Fleming (2000:470) emphasises the role of reading and literature in the generation of knowledge and identity formation:

Reading gives us articulation of ourselves, solidity where before there was only the empty air of experience. Words, pictures, conceptualizations of ourselves: this is knowledge, initially about ourselves and perhaps later by extension about others.

Felicity Rosslyn (1999) expands on the versatility and value of stories when she reports on a seminar held in collaboration with psychiatrists, psychotherapist and social workers at a hospital in England. In her seminar she strives to convince a sceptical audience that most people use stories to perform their jobs, but only in different ways. She mentions four basic aspects about stories that correlate with psychological practices, but would also apply to many other activities and professions.

- The first one is the "Arabian Nights effect" which encourages the sharing of stories which, as Rosslyn (1999:22) astutely notes, allows her students to express the need to "feed their hunger for stories, in and of themselves". I recently had such an experience when several of my first year students had to write an essay on Holden Caulfield's feelings of insecurity in The Catcher in the Rye. I was astounded how many of them actually bared their souls in the process. 
- The second aspect of story telling concerns "authenticity", which I discussed to some extent in the skills-knowledge debate above. It concerns the distinction between "learning as an emotional experience, and learning as the acquisition of a commodity".

- The third aspect is related to "modelling" and how students are either inspired or discouraged by their lecturer in their experience of literature. Such a situation could be avoided if there were a dynamic interaction between the facilitator and the learner.

- The final aspect involves "learning from archetypes", that is, the reader's participation in the evolution of the plot and his/her reaction to situations and complications - the experience of role models.

Another example of the versatility of stories can be identified in or traced to our daily newspapers. Michael Chapman (2000:48-49) points out, that although newspapers have to observe specific conventions and norms, they still deal with stories within a specific society. The fact remains that "there are in fact different sets of stories within different media" (2000:59). Especially newspaper reporters should show an ability to contextualise their stories; possess a store of general knowledge; have effective life skills and evince a reading culture with an interest in the gathering and processing of news-worthy events. Yet, as briefly highlighted on a news broadcast on the SABC in 2002, a survey conducted by the South African National Editors' Forum found young reporters at the time to be sadly lacking in most of these skills. This assessment, in my literary opinion, could be directly related to their superficial focus on skills instead of a basic grounding in literature, genres and context.

\section{Conclusion}

Our lives could be compared to a complex network that becomes dysfunctional when vital links are missing, or an ecosystem that dies when species become extinct. We need all the pieces of the jigsaw puzzle to understand the pattern and picture of life in order to generate wisdom and formulate a world-view. Through literature, the human being can explain (natural sciences), understand (humanities) and preserve (history) his environment, hone his intellectual abilities (relating to other relevant disciplines as well) and exercise and express his spiritual needs (religion). In contrast, Radovan (2002:59) mentions the negative influence of technology on personal identity, claiming that it imposes its own values and 
"threatens basic feelings of identity in traditional cultures and communities". Radovan refers to television and the internet as good examples of this effect (Radovan, 2002:61) and points out that these media have mainly been interested in the facilitation of profit rather than the distribution of knowledge. Literature not only encourages the development of a personal identity that transcends "locality, class and even nation itself" (Quirk, 2000:10), but as Rosslyn (1999:25) believes, it provides a type of metaphysical security that she explains in the following way:

Literature is, in a sense, a record of the human experience thus far, and it reassures us that whatever trials we find ourselves facing, they are known, and named. Many others have experienced what we are experiencing - and the world of human beings itself can be viewed as a 'therapeutic community' to which each of us, however unique, automatically belongs.

\section{List of references}

BLOKLAND, HANS. 1998. Kiezen tussen Bach en Madonna: Tussen emancipatie en paternalisme: Cultuurspreiding en de overheid. Ons Erfdeel: Algemeen-Nederlands Tweemaadelijks Cultureel Tijdschrift, 41(1):59-71.

CHAPMAN, MICHAEL. 2000. Rebranding English till it hurts. The English Academy Review, 17:44-54.

CHETTY, R.P. 2000. Critical educational studies: A shift from Freirean critical consciousness to Foucauldian discourse formation in the teaching of South African literature in higher education institutions. South African Journal of Higher Education, 14(1):13-19.

DASENBROCK, REED WAY. 1987. Intelligibility and meaningfulness in multicultural literature in English. Publications of the Modern Language Association, 102(1):10-19.

DULLAART, GERDA. 2002. Subjekvorming deur literatuuronderrig aan universiteite in Suid-Afrika sedert 1994. Potchefstroom: PU vir CHO. (Ongepubliseerde Ph.D.-proefskrif.)

FLEMING, BRUCE E. 2000. What is the value of literary studies? New Literary History: A Journal of Theory and Interpretation, 31(3):459-476.

HAAHR, MADS. 2002. Information jockey: The dubious role of the 21st century academic. Southern Review, 35(2):71-87.

HASSAN ROBERT. 2002. Time and knowledge in the information ecology. Southern Review, 35(2):16-36.

KISSACK, MIKE. 2001. Combatting consensus: The value of conflict and controversy for literary education in South Africa. The English Academy Review, 18:87-99.

KLOPPER, DIRK. 2000. Editorial: Glad to be of use. The English Academy Review, 17:1.

MOHANTY, SATYA P. 2001. Can our values be objective? On ethics, aesthetics, and progressive politics. New Literary History: A Journal of Theory and Interpretation, 32(4):803-833. 
MULDOON, PHYLLIS A. 1990. Challenging students to think: Shaping questions, building community. English Journal, 79(4):34-40.

NELSON, BRENDAN. 2002. The study of education and humanities versus skill-based competencies. Southern Review, 35(2):5-15.

PALAZZO, LYNDA. 1990. University English departments in a changing society. (In Wright, L., ed. Teaching English literature in South Africa: Twenty essays. Grahamstown: Institute for the study of English in Africa, Rhodes University. p. 139-151.)

PETERS, MICHAEL. 2002. Universities, globalisation and the knowledge economy. Southern Review, 35(2):16-36.

PHELPS DEILY, MARY-ELLEN. 2002. Teaching quality viewed as crucial. Education Week: American Education's Newspaper of Record, 21(42):5.

QUIRK, RANDOLPH. 2000. Language and identity. The English Academy Review, 17:2-11.

RADOVAN, MARIO. 2002. Know-how and do not ask why. Southern Review, 35(2):55-70.

ROSSLYN, FELICITY. 1999. Literature in analysis: Some clinical parallels. Poetry Nation Review, 25(6):22-26.

SCHICK, IRVIN CEMIL. 1999. The erotic margin: Sexuality and spatiality in alteritist discourse. London: Verso.

SOUTH AFRICAN NATIONAL EDITORS' FORUM. 2002. SABC News Report.

SWART, MARIEKEN. 2000. On canons and harlots: Repositioning English. The English Academy Review, 17:65-73.

VAN SCHALKWYK, P.L. 2003. Horisonne: Mites oor die moontlike in kontemporêre verhalende tekste van Suid-Afrika en die Nederlandse taalgebied. Potchefstroom: PU vir CHO. (Ongepubliseerde Ph.D.proefskrif.)

WRIGHT, LAURENCE. 1999. Culture and civilisation in South Africa: Some questions about the "African Renaissance". The English Academy Review, 16:60-73.

\section{Key concepts:}

critical thinking

literature and identity

stories

the humanities and teaching skills and knowledge

\section{Kernbegrippe:}

die humanoria en die onderrig van vaardighede en kennis

kritiese denke

letterkunde en identiteit

stories 